PART 1

The Diplomatic Stage 
Linda Frey and Marsha Frey - 9789004304789 Downloaded from Brill.com@4/26/2023 09:57:30AM via free access 


\title{
The Olive and the Horse: The Eighteenth-Century Culture of Diplomacy
}

\author{
Linda Frey and Marsha Frey
}

The diplomats who gathered in the picturesque town of Utrecht to end the wars fought in Europe as well as overseas acted on a public parquet. Their intrigues, maneuvers, negotiations, quarrels, and social activities, sometimes including sexual liaisons, were part of the public performance of peace. These representatives could not but be conscious of their role in this performative culture and be adept at its manipulation. The sociability of this international elite so integral to the ancien régime facilitated the deliberations. In the eighteenth century those who served abroad, whom Napoleon would later derisively dub 'the brilliant butterflies of the panniers age,' community, according to the astute and knowledgeable envoy of Louis XIV, François de Callières $\left(1645^{-1717}\right) .^{2}$ Just as the states of Europe were part 'd'une même République, ${ }^{3}$ so diplomats were part of a narrow elite; they shared similar sentiments, norms and values, were bound by personal and family alliances, and understood the implicit 'code' 'rooted in ceremonial forms and gestures.' That assessment was shared at the end of the eighteenth century by VictorFrançois, duc de Broglie (1718-1804) who compared this group to 'un grand ordre de chevalerie'. To belong to this 'milieu élégant et raffiné' one needed to

1 Napoleon's Letters to Marie Louise, ed. Charles de La Roncière (New York: Farrar \& Rinehart Inc., 1935), 15 July, 1813, 169.

2 François de Callières, On the Manner of Negotiating with Princes, trans. A.F. Whyte (Washington D.C.: University Press of America, 1963), 113.

3 Callières, On the Manner of Negiotating with Princes, 11.

4 Hamish Scott, 'Diplomatic Culture in Old Regime Europe,' in Cultures of Power in Europe during the Long Eighteenth Century, ed. Hamish Scott and Brendan Simms (Cambridge: University Press, 2007), 58-85: 60, 77; Lucien Bély, 'Méthodes et perspectives dans l'étude des négociations internationales à l'époque moderne,' Frankreich im europäischen Staatensystem der Frühen Zeit, ed. Rainer Babel (Sigmaringen: Jan Thorbecke Verlag, 1995), 219-233: 223 and Claire Béchu, 'Les Ambassadeurs français au xviiie siècle: Formation et carrière,' L'Invention de la diplomatie, Moyen Âge-temps modernes, ed. Lucien Bély and Isabelle Richefort (Paris: Presses universitaires de France, 1998), 331-346: 345 .

(C) KONINKLIJKE BRILL NV, LEIDEN, 2015 | DOI 10.1163/9789004304789_003 
be 'de la famille.' Antoine Pecquet ( $1700-1762)^{6}$ who served as premier commis of foreign affairs from 1725 to 1740 - said much the same. Foreign representatives abroad formed 'une espèce de société indépendante,' bound together by a 'une communauté de priviléges.' ${ }^{7}$ By the outbreak of the Revolution a 'distinct diplomatic culture' that was both 'cohesive' and 'homogeneous' existed ${ }^{8}$ and unified the diplomatic world. ${ }^{9}$

\section{Men of War and of Peace}

The individuals who belonged to this 'distinctive community' came from the same social class, the nobility - and more often than not the upper ranks, and dominated the diplomatic corps, especially the ranks of ambassador and minister plenipotentiary, which inevitably came to be permeated with a 'noble ethos.'10 A prosopographical study of $45^{\circ}$ diplomatic agents between 1697 and 1715 underscores the critical importance of birth. These negotiators were from either the noblesse de l'épée (the nobles of the sword), the noblesse de la robe, or the clergy. For certain families diplomatic service became a tradition. For example, Jean d'Estrées, abbé de Saint Claude, succeeded his uncle, César, cardinal d'Estrées as ambassador of France at Madrid just as Jean Louis d'Usson, marquis de Bonnac followed his uncle, François d'Usson, marquis de Bonrepaus at the United Provinces. ${ }^{11}$ Yet another prosopographical study of French diplomats who held the rank of minister plenipotentiary or ambassador between 1715 and 1791 shows that of the 179, $120(67 \%)$ had also served in the military. ${ }^{12}$ In France by 1789 nobles held 35 of the 39 diplomatic posts;

5 Quoted in Jacques Henri-Robert, Dictionnaire des diplomates de Napoleon, histoire et dictionnaire du corps consulaire et imperial (Paris: Henri Veyrier, 1990), 13.

6 François Michaud, Biographie universelle ancienne et moderne (Michaud: Paris, 1854), reprint (Graz: Akademische Druck u. Verlagsanstalt, 1967) 32: 341. See also Béchu, 'Les Ambassadeurs français au xviiie siècle,' 335 .

7 Antoine Pecquet, De l'Art de négocier avec les souverains (The Hague: Jean van Duren, 1738), 104.

8 Scott, 'Diplomatic Culture,' 59. See also Hamish Scott, The Birth of a Great Power System, 1740-1815 (Harlow, England, 2006), 4-5.

$9 \quad$ Lucien Bély, Espions et ambassadeurs au temps de Louis XIV (Paris: Fayard, 1990), 748.

$10 \quad$ Scott, 'Diplomatic Culture,' 72.

11 Bély, 'Méthodes et perspectives,' 222.

12 Béchu, 'Les Ambassadeurs français,' 333. See also Simon Surreaux, Les Maréchaux de France des Lumières: histoire et dictionnaire dans la société d'Ancien Régime (Paris: Spm, 2013). 
the other four, such as Danzig, were minor postings. ${ }^{13}$ Because many of the diplomats also belonged to the noblesse de l'épée and had attained the rank of general officer, a close relationship between the army and the diplomatic corps existed. Both Lucien Bély's and Claire Béchu's analyses demonstrate that diplomats were selected in large part from the military. ${ }^{14}$ That linkage is also seen during the War of the Spanish Succession. In the case of Great Britain, Henry Snyder has pointed out that all the major diplomatic posts (The Hague, Brussels, Lisbon, Vienna, Berlin, Hanover and Spain) at one time during that conflict were held by military officers, many with close ties to Marlborough. ${ }^{15}$ That link underscores the primacy of birth in the diplomatic corps of the Old Regime for only those of the highest social status were selected to represent the king, particularly at the rank of ambassador. Marlborough, who was accredited to several courts and shuffled among others, showed his prowess in both military and diplomatic tactics. The comte de Tallard had the distinction of negotiating the Partition Treaties of 1698 and 1700 designed to avoid war and, after they were shattered, of fighting in the ensuing conflict and earning a marshal's baton. Captured at the battle of Blenheim as a prisoner of war, he intrigued with his many friends in England, helped bring down the Whigs, and was subsequently released without ransom, perhaps as a gesture of gratitude. ${ }^{16}$ João Gomes da Silva, count of Tarouca, fought before he negotiated as first plenipotentiary of Portugal at Utrecht. The famous cavalry commander Reinhart Vincent, Freiherr von Hompesch often engaged in both military and diplomatic skirmishes. ${ }^{17}$ The Swiss, François-Louis de Pesmes, often called SaintSaphorin, both a general and a diplomat, assisted the Dutch, the Habsburgs, the Prussians, the Swiss, and finally the British. With less happy consequences, Raimond-Balthazar Phélypeaux de Verger had served as envoy extraordinary before being promoted to lieutenant general. Dispatched on an almost impossible mission, anticipating the intentions of the duke of Savoy, Phélypeaux

13 Melvin Edelstein, 'La Noblesse et le monopole des fonctions publiques en 1789,' Annales historiques de la Révolution française 54 (1982): 440-443, 441.

14 Bély, 'Méthodes et perspectives,' 222 and Béchu, 'Les Ambassadeurs français,' 333.

15 Henry L. Snyder, 'The British Diplomatic Service during the Godolphin Ministry,' in Studies in Diplomatic History, ed. Ragnhild Hatton and M.S. Anderson (North Haven, Ct: Archon Books, 1970), 47-68: 6o, 63.

16 Ronald S. Love, 'Camille, comte de Tallard, marquis de la Beaume-D'Hostun, Baron d'Arlanc,' in The Treaties of the War of the Spanish Succession: An Historical and Critical Dictionary, ed. Linda Frey and Marsha Frey (Westport, Ct: Greenwood Press, 1995), 433-434.

17 Augustus J. Veenendaal, Jr. 'Reinhart Vincent, Freiherr von Hompesch,' in The Treaties of the War of the Spanish Succession: An Historical and Critical Dictionary, ed. Frey and Frey, 209-210. 
was ordered to act as field marshal except when he was acting as ambassador. It did not go well. Phélypeaux's difficult personality only alienated the duke who took him hostage and declared war against France. ${ }^{18} \mathrm{~A}$ less well known example, János Erdődi, Gróf Pálffy, the commander in chief of the imperial armies in Hungary, built up personal contacts that expedited his negotiations of the peace of Szatmár. ${ }^{19}$ In all of the above cases and doubtless in many others the Old Regime saw no contradiction in selecting ambassadors to conclude the peace from men of war. As one contemporary noted: 'La carrière politique n'a jamais été regardée comme une discontinuation de la carrière militaire. ${ }^{20}$ That same nexus between soldiers and diplomats, albeit with different personnel, would recur later in the Revolution and under Napoleon. Whether they offered the olive, peace, or brought the horse, war, they shared a code of conduct that dictated dress, language, and etiquette. As Bély has argued, this 'social and cultural coherence' facilitated international discussions by making possible a common language and creating certain expectations. ${ }^{21}$

\section{The Issue of Training}

The demands of the developing international system in an age of endemic warfare forced many to realize the importance of diplomacy and to consider more formal training for the men sent abroad. The impetus to establish such a school was echoed in the earlier attempts of Philip II and of the papacy in the Pontifical Academy of 1701 and later of Frederick II. ${ }^{22}$ The best-known attempt, Torcy's short-lived Académie politique, had been founded in $1712 .{ }^{23}$ It is not

18 Linda Frey and Marsha Frey, 'Raimond-Balthazar Phélypeaux de Verger,' in The Treaties of the War of the Spanish Succession: An Historical and Critical Dictionary, ed. Frey and Frey, 352-353.

19 Peter F. Sugar, 'János Erd Erdödi, Gróf Pálffy', in The Treaties of the War of the Spanish Succession: An Historical and Critical Dictionary, ed. Frey and Frey, 328-329.

20 Béchu, 'Les Ambassadeurs français,' 333.

21 Bély, Espions et ambassadeurs, 289.

22 Karl Schweizer, 'François de Callières and the marquis de Torcy's 'Political Academy': New Evidence,' Canadian Journal of History 46: 3 (2011): 619-625, 619 .

23 For the short-lived academy founded by Torcy see Guy Thuillier, La première École d'administration: L'Académie politique de Louis XIV (Paris: Librairie Droz, 1996). See also John Rule with Ben Trotter, Diplomacy and Administration under Louis XIV: Colbert de Torcy and the Department of the Secretary of State for Foreign Affairs, 1689-1715, forthcoming; Maurice Keens-Soper, 'The French Political Academy 1712: A School for Ambassadors,' European Studies Review 2 (1972): 323-355; Klaits, 'Men of Letters', 577-597. 
surprising that Torcy turned to an experienced diplomat, Callières, who had championed the idea of a professional diplomatic corps. ${ }^{24}$ Later in the century the French Ministry of Foreign Affairs did send some promising individuals to the diplomatic school at Strasbourg, founded by Jean Daniel Schoepflin $(1694-1771)^{25}$ and subsequently directed by his pupil, Christophe Guillaume Koch (1737-1813), a professor of law, who presided over the diplomatic committee prior to the fall of the monarchy. Many diplomats who would serve the revolutionary governments, however briefly, attended Strasbourg, such as Bourgoing, Ségur, Bombelles, Custine, Bacher, and Talleyrand, as well as their counterparts from other countries, such as Clemens Wenzel Lothar, Prince Metternich (Holy Roman Empire); Maximilian Josef, Freiherr von Montgelas (Bavaria); and Morton Frederick Eden, Baron Henley (Great Britain). There they studied international law, statistics, and history and forged bonds that would persist in their later lives. ${ }^{26}$

\section{Diplomatic Manuals}

Although many of these attempts were short lived, there were manuals to guide those who sought to serve as diplomats. For many Callières' now classic work, On the Manner of Negotiating with Princes, written in 1716, epitomized the ideals of the diplomacy of the old regime. These norms were widely shared and can be seen as well in the works of one of his contemporaries, Louis Rousseau de Chamoy (1645?-1711). ${ }^{27}$ In Callières' view rulers should appoint men who were both prepared and able for a state's fate often depended on the envoy. In particular 'men of birth and breeding' and wealth were best able to represent France because their rank would entitle them to respect. Those of good birth, he assumed, would also have certain 'qualities' necessary for success. The successful envoy was suave, personally agreeable, able to adapt to different cultures and to appreciate the positive features of the country where he was sent.

24 Schweizer, 'François de Callières', 622.

25 Michaud, Biographie universelle ancienne et moderne 38: 407-409.

26 Jürgen Voss, 'Christophe Guillaume Koch (1737-1813): Homme politique et historiographe contemporain de la Révolution,' History of European Ideas 13:5 (1991): 531-543: 531-532. See also Jean Richtereau, Le Rôle politique du professor Koch (Strasbourg: Imprimerie Alsacienne, 1936) and Michaud, Biographie, 22: 84-86.

27 Louis Rousseau de Chamoy, L'Idée du parfait ambassadeur (Paris: A. Pedone, 1912). Chamoy's work was written in 1697 and reflected his extensive diplomatic experience. He served the king abroad as secretary, chargé d'affaires, resident, envoy, and plenipotentiary. 
He was also affable, had excellent manners, and was courteous 'in little things.' Because the envoy represented his ruler he must have an unshakeable dignity. In brief, rulers should avoid sending the least gifted and rely on the ablest. Callières approvingly cited the remark of the grand duke of Tuscany who, although admitting that Tuscany had 'fools,' was careful 'not to export them.'28

Some two decades later in 1737, Antoine Pecquet, an admirer of Callières, echoed his views. Pecquet too disputed the idea that all men could be excellent negotiators. Rather the prince should select 'l'homme du monde' who could excel in what he termed 'le théâtre du monde.'29 For him, as for Callières, a successful envoy had to possess certain essential characteristics. For envoys of the first rank, that is, ambassadors, individuals had to be of great birth or great achievement. Those of lesser distinction could be chosen for the lower ranks. The envoy's ability to excel in a foreign society helped to ensure ultimate success. The first duty of the envoy was to project not only 'politesse' but good will. To do that he must respect the laws and customs of the country and follow court ceremonial. ${ }^{30}$

The views of those within the diplomatic establishment were eerily similar almost a hundred years later. William Eden, Lord Auckland (1744-1814), who had served as British ambassador to Spain and the United Provinces and special envoy to France, echoed Callières' advice and urged those going abroad to be well acquainted not only with their own country and its colonies but also with all the states of Europe, their sovereigns and ministers. The envoy should, moreover, be fluent in French, able to write well in English (if employed by the British), and well versed in the etiquette of courts, the law of nations and existing disputes. ${ }^{31}$ Still those who proffered the olive branch of peace, including those who rode the horse of war, shared a code of conduct that dictated dress, language, and etiquette.

\section{Ceremony and Etiquette}

They would not have recognized these issues as ones of mere style, for such customs validated the ancien régime and reinforced the aristocratic code.

\footnotetext{
28 De Chamoy, L'Idée du parfait ambassadeur, 56-57, 40-46, 49, 124-127, 24, 21-22, 59, 142.

29 Pecquet, De l'Art de négocier, $\mathrm{x}, \mathrm{xii}, \mathrm{xxvi-xli}$.

30 Pecquet, De l'Art de négocier, 106-107, 2, 5, 10-13, 24-30, 32-37, 38-42, 46, 44-46, 50, 70, 49-51, xv, 57, 110, 58-59.

31 William Eden, first baron Auckland, The Journal and Correspondence of William, Lord Auckland (London: Richard Bentley, 1862), 3: 329-330, 20 February 1796.
} 
The minutely regulated ceremonies were part of what Duindam calls 'the public presentation of power. ${ }^{32}$ Historians have come to recognize that 'symbolics of power' [were] not mere incidental ephemera. ${ }^{33}$ For Louis XIV etiquette was an instrument of power: 'Those people are gravely mistaken who imagine that all this is mere ceremony. ${ }^{34}$ Those at the court became sensitized to 'the status and importance that should be attributed to a person in society on the basis of his bearing, speech, manner or appearance. 35 The nobility were caught in 'the vicious circle of enforced ostentation,' 'imprisoned by their own ceremonial and etiquette, ${ }^{36}$ like an insect imprisoned in amber. This 'incessant competition' meant that 'everyone was running on the spot.' ${ }^{37}$ To 'keep one's place in the intense competition,' one had to cultivate the appropriate gestures, move in the rigidly mandated way, wear the right fabrics, choose the correct shoes. As Elias noted, 'Even smiling is shaped by court custom. ${ }^{38}$ A satire dating from the reign of Henry IV has one courtier explain to another the minutiae of dress (high heels, gilded spurs), what to say, when to laugh, how to move the head, when to fling your arms, when to shift from one foot to another, etc. ${ }^{39}$ A diplomat who was, nonetheless, not part of the courtly elite, Callières condemned the 'vain ceremonies,' which he equated with a 'play' in which the courtiers

32 Jeroen Duindam, Vienna and Versailles: The Courts of Europe's Dynastic Rivals, 1550-1780, (Cambridge: Cambridge University Press, 2003), 181. See also Ute Daniel, 'Überlegungen zum höfischen Fest der Barockzeit,' Niedersächisches Jahrbuch für Landesgeschichte 72 (2000): 45-66; Benjamin Marschke, 'Von dem am Königl. Preussischen Hofe abgeschafften Ceremoniel': Monarchical Representation and Ceremony in Frederick William I's Prussia,' in Orthodoxies and Diversity in Early Modern Germany, ed. by Randolph C. Head and Daniel Christensen, 227-252 (Boston: Brill Publishers, 2007); Miloš Vec, Zeremonial-Wissenschaft im Fürstenstaat: Studien zur juristischen und politischen Theorie absolutischer Herrschaftsrepräsentation (Frankfurt am Main: Vittorio Klostermann, 1998) and Barbara von Stollberg-Rilinger, 'Zeremoniell, Ritual, Symbol: Neue Forschungen zur symbolischen Kommunikation im Spätmittelater und Früher Neuzeit,' Zeitschrift für historische Forschung 27 (2000): 389-405.

33 David Cannadine, 'Introduction: Divine Rites of Kings,' in Rituals of Royalty: Power and Ceremonial in Traditional Societies, ed. David Cannadine and Simon Price, (Cambridge: University Press, 1987), 3 .

34 Norbert Elias, The Court Society, trans. Edmund Jephcott (New York: Pantheon, 1983), 117-118.

35 Elias, The Court Society, 55 .

36 Elias, The Court Society, 71, 207.

37 Elias, The Court Society, 207-208.

38 Elias, The Court Society, 232.

39 Quoted in Elias, The Court Society, 231. 
were 'comedians. ${ }^{40}$ Later in the century François Gabriel, Comte de Bray (1765-1832), who was sent as French representative to the Diet of Ratisbon and who resigned in August 1792, found the etiquette a 'labyrinth,' such that one cannot find one's way after one enters: the number of steps to advance or to retreat, the number of bows was counted and predetermined. When to put on one's hat and when to remove it was stipulated. 'All this is almost as difficult to study as one of the most important rules of [the French mathematician] Bezout. ${ }^{41}$ The magnificent clothing, the pompous ceremonial, the march that lasted two and half hours combined with visits, ceremonies, fêtes, and dinners made him deplore the time lost. This is 'an abominable business,' he lamented, 'with such 'oppressive vanities.' He deplored the five-hour ceremonial, the reception line that lasted three and a half hours, the 'fatiguing luxury'. In short, he found this way of life 'miserable. ${ }^{42}$

The absolutist and authoritarian ancien régime encoded hierarchy in a representational system, by which is meant, according to Blanning, 'the making present of authority by dress, ritual, painting, architecture, theatrical performance or any other form of display. ${ }^{43}$ As members of the 'distinctive diplomatic culture' that evolved in the long eighteenth century, they were part of an 'independent society', so termed by an official of the foreign ministry, Antoine Pecquet in $1737 .{ }^{44}$ Drawn from an aristocratic elite, these individuals shared certain assumptions because 'diplomacy itself assumed many of the characteristics of the aristocratic-courtly and cosmopolitan culture of the period: ${ }^{15}$ Not incidentally, court and embassy reinforced the ceremonial of each.

In the ancien régime, states manipulated etiquette to advance social status, just as the aristocracy did. Not surprisingly, such discussions dominated diplomatic manuals and legal treatises. The classic work The Law of Nations; or, Principles of the Law of Nature Applied to the Conduct and Affairs of Nations and Sovereigns by Emerich de Vattel first appeared in 1758. That well-known jurist noted that 'at present kings claim superiority of rank over republics. ${ }^{46}$

40 François de Callières, Letters (1694-1700) of François de Callières to the Marquise d'Huxelles, ed. Laurence Pope and William Brooks (Lewiston: Edwin Mellen Press, 2004), 228.

41 Comte F.-G. de Bray, Mémoires du comte de Bray (Paris: Plon Nourrit et Cie., 1911), 103.

42 Bray, Mémoires du comte de Bray, 109, 111, 120.

43 T.C.W. Blanning, 'Frederick the Great and German Culture,' in Royal and Republican Sovereignty in Early Modern Europe, ed. Robert Oresko, G.C. Gibbs and H.M. Scott (Cambridge: University Press, 1997), 527-550: 529-530.

44 Scott, 'Diplomatic Culture,' 59-60.

45 Scott, 'Diplomatic Culture,' 62

46 Emerich de Vattel, The Law of Nations; or, Principles of the Law of Nature Applied to the Conduct and Affairs of Nations and Sovereigns (Philadelphia: T. and J.W. Johnson and Co., 1863), 149 . 
The jurist Georg Friedrich Martens, whose treatise appeared in French in 1789 , included an extensive section on precedence and not incidentally appended advice on how to avoid the disputes which bedeviled early modern diplomacy. ${ }^{47}$

As the historian Jeremy Black pointed out, diplomats used ceremonial and protocol 'as a means of asserting and defending status and interests. It was perfect for a competitive world that wished to have an alternative to conflict.'48 Diplomats were ordered to engage in a kind of 'ceremonial brinkmanship as they sought to defend and enhance the prestige of their masters. 49 Precedence was so vigorously contested because it reflected a state's power, what the comte de Broglie called, the 'interest of regard. 50 The courtiers were so obsessed with rank and with deportment because such maneuvering was 'a zero-sum game: the gains of one entailed the other's losses. ${ }^{51}$ Probably no one played that game as well as the French. Jean Baptiste Colbert, marquis de Torcy, the secretary of foreign affairs under Louis XIV, an adept practitioner of the art, noted that these 'trifles of etiquette' signaled the importance of a country, affirmed its power, and helped to establish its grandeur. When the king of Denmark announced that he would in the future receive the French envoys as Louis received his, that is, seated and covered, Louis XIV refused to accept this change. Torcy underscored that to accept an inferior ranking or even to consent under the 'pretext of politeness or equality and the suppression of all prerogatives' would be to 'recognize and admit the decline of the country. 52

These 'subtle games of ceremonial' undergirded what Lucien Bély dubs the 'société des princes. ${ }^{53}$ In that 'collective construction' ceremony served not only as a 'political instrument in the relations between European states, but also as a mark of solidarity in the society of princes. ${ }^{54}$ The sovereigns, in Bély's words, made up a rather 'singular' family whose relations were ritualized to such an

47 George Friedrich Martens, Summary of the Law of Nations (Philadelphia: Thomas Bradford, 1795), 136-144. The French edition of 1789 Précis du droit des gens modernes de l'Europe was a revision of an earlier work in Latin.

48 Jeremy Black, British Diplomats and diplomacy, 1688-180o (Exeter: University of Exeter Press, 2001), 97 .

49 Duindam, Vienna and Versailles, 184.

$50 \quad$ Scott, The Birth of a Great Power System, 124.

51 Scott, The Birth of a Great Power System, 124.

52 Jean Baptiste Colbert, Journal inédit de Jean-Baptiste Colbert, marquis de Torcy, ed. Frederic Masson (Paris: Plon Nourrit, 1884), xiii-xiv.

53 Lucien Bély, La Société des princes: XVI ${ }^{e}-X V I I I^{e}$ siècle (Paris: Fayard, 1999), 406, 396.

54 Lucien Bély, 'Souveraineté et souverains: la question du cérémonial dans les relations internationales à l'époque moderne,' Annuaire-bulletin de la Société de l'histoire de France 130 (1993): 27-43, 43 and 28. 
extent that even war did not hamper or impede 'une politesse internationale.'55 'La société polie,' that very strict code of manners, had evolved at the court society. That 'universe of usage'56 both underscored and reinforced the prestige of the upper classes.

\section{Aristocratic Code}

The aristocratic code mandated what the age called 'honest dissimulation,' which meant 'that whatever you felt or thought, you must behave according to the rules of politeness' and you must do so seemingly without effort, with what Castiglione, the quintessential courtier, called grace or 'sprezzatura [nonchalance.] ${ }^{57}$ This theme of repression (and suppression) of emotions was epitomized at Versailles. 'The practice of honest dissimulation,' as Snyder has argued, 'was dialectically linked to the Old Regime culture of display and observation. ${ }^{58}$ The aristocratic injunction mandated that a gentleman only walks, never runs and that he enters a room langsam und feierlich, in a slow and solemn manner. Diplomats mastered phatic communication, that is, 'greetings, phrases, and gestures employed to convey general sociability rather than to transmit specific meaning. ${ }^{59}$ Diplomats understood only too well what Raymond Cohen has pointed out, that the 'threshold moments' of greeting and parting 'define the nature of the social relationship between the participants.' 60 Under the carapace of the international system lurked what Blanning has dubbed 'the culture of power' and what Shakespeare called 'dissembling courtesy.' ${ }^{\prime}$ Blanning notes that Louis XIV's authority was 'as much a cultural as a military or diplomatic construct.' 62 A critical American at the Court of St. James, John Adams, lamented that 'There are a train of ceremonies

55 Bély, 'Souveraineté et souverains,' 28, 35. See also Daniel, 'Überlegungen zum höfischen Fest der Barockzeit,' 45-66 and Stollberg-Rilinger, 'Zeremoniell, Ritual, Symbol,' 389-405.

56 Bély, La Société des princes, 10.

57 Edward Muir, Ritual in Early Modern Europe (Cambridge: Cambridge University Press, 1997), 120.

$5^{8}$ Jon R. Snyder, Dissimulation and the Culture of Secrecy in Early Modern Europe (Berkeley: University of California Press, 2009), 47.

59 Muir, Ritual in Early Modern Europe, 125.

6 Raymond Cohen, Theatre of Power: The Art of Diplomatic Signalling (New York: Longman, 1987), 90-91.

61 Shakespeare, Cymbelline, I, I, 84 quoted in Dissimulation and the Culture of Secrecy, 33.

62 T.C.W. Blanning, The Culture of Power and the Power of Culture: Old Regime Europe 166o1789 (Oxford: Oxford University Press, 2002), 5 . 
yet to go through... It is thus the essence of things is lost in ceremony in every country of Europe. We must submit to what we cannot alter. Patience is the only remedy' 63

\section{Role of Language}

Language buttressed the court society. It was not accidental that the diplomat Callières $\left(1645^{-1717}\right)$ who wrote the seminal tract On the Manner of Negotiating with Princes also composed two works on civility: Des mots à la mode et des nouvelles façons de parler (1692) and De la science du monde et des connaissances utiles à la conduite de la vie (1717). In the first essay this quintessential insider describes the court vocabulary as a 'strange jargon'64 and in another as 'a certain kind of singular language which one uses at certain times and among certain persons. ${ }^{65}$ Diplomats who operated in an international arena were more steeped in that usage than most inside the court society. To a man like Talleyrand, who straddled both worlds, the language of the court suffered from an 'excess of words which impoverished it.' The 'polite' language of monarchical France, he complained, was pauperized by its vices. Its 'ancient obsequious forms' reflected the 'ruinous luxury' of the court. 'In this paradoxical logic, abundance became misery, the multiplication of periphrases, the circumlocution, and other superfluities added to the destitution. 66

\section{Importance of Dress}

Dress like language reflected and reinforced the aristocratic society and the hierarchical code. What Daniel Roche has termed the ancien régime's elaborate 'culture of appearances' 'had provided an established set of assumptions about the legibility of identity and status through varieties of dress' and mandated

63 Quoted in Ideas and Diplomacy: Readings in the Intellectual Tradition of American Foreign Policy, ed. Norman A. Graebner (New York: Oxford University Press, 1964), 36.

64 Des mots à la mode et des nouvelles façons de parler, quoted in Daniel Gordon, Citizens without Sovereignty Equality and Sociability in French thought, 1670-1789 (Princeton, New Jersey: Princeton University Press, 1994), 105.

65 See François de Callières, Du bel esprit (Amsterdam: Pierre Brunel, 1695), 16.

66 Philippe Roger 'Le Débat sur la 'langue révolutionnaire,' in La Carmagnole des muses: l'homme de lettres et l'artiste dans la Révolution (Paris: Armand Colin, 1988), 177-178. 
displays of magnificence. ${ }^{67}$ This lexicon of words, gestures, symbols, and garb was consciously adopted. The deployment of symbols, the utterance of specific phrases coupled with certain intonations, and the wearing of a distinctive dress were visible manifestations of the diplomatic culture and of the international system. In the words of Burke, 'no citizen of Europe could be altogether an exile in any part of it. ${ }^{\prime} 8$

\section{Significance of Congresses}

For Bély the congress of peace 'the incarnation of possible international accord, brought a message of peace for the world. ${ }^{69}$ For him the congress was 'a symbolic image of international sociability.70 Indeed festivities dominated the agenda at Baden with its balls, fêtes, plays, and musical performances, not to mention multi-course banquets. It was no accident that one of the French representatives, Charles-François, comte de Vintimille du Luc, brought actors, musicians, and ballerinas along with chefs and forty pages. Indeed that congress could share with the later congress at Vienna the appellation 'the dancing congress. ${ }^{71}$ Such sociability buttressed the social ties and underscored the 'relative cultural and social homogeneity of the negotiators' that served as the backdrop of all international encounters. ${ }^{72}$ That homogeneity 'reaffirmed by the social practices of diplomacy', facilitated political discussion and reinforced cosmopolitanism. ${ }^{73}$ The similitude of gestures, words and attitudes eased communication. ${ }^{74}$ In this theatre of Europe certain rituals honed by usage and by tradition limited war. ${ }^{75}$ What undergirded the international order was an aristocratic sociability that would be lost later in the revolutionary era.

67 Richard Wrigley, The Politics of Appearances: Representations of Dress in Revolutionary France (Oxford: Berg, 2002), 232.

68 Edmund Burke quoted in Gerald W. Chapman, Edmund Burke: The Practical Imagination (Cambridge, Mass: Harvard University Press, 1967), 185-186.

69 Bély, Espions et ambassadeurs, 374.

70 Bély, Espions et ambassadeurs, 374-375.

71 Linda Frey and Marsha Frey, 'Baden,' in The Treaties of the War of the Spanish Succession, ed. Frey and Frey, 26.

72 Bély, Espions et ambassadeurs, 374.

73 Bély, Espions et ambassadeurs, 374.

74 Bély, Espions et ambassadeurs, 402.

75 Bély, Espions et ambassadeurs, 377. 
That system with its implicit ideological underpinnings enmeshed diplomats in that 'ghostly perpetuum mobile': the etiquette, the ceremonial, and the language of court society. ${ }^{76}$ Burke saw in this sublimation of emotions a certain 'elegance of mind and manners. ${ }^{77}$ Such things as manners were not insignificant; Burke argued that they were more important than laws. 'Manners are what vex or soothe, corrupt or purify, exalt or debase, barbarize or refine us, by a constant, steady, uniform, insensible operation, like that of the air we breathe

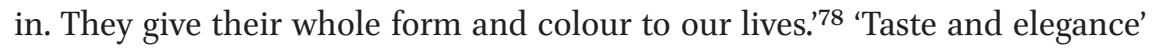
Burke argued, 'though they are reckoned only among the smaller and secondary morals, yet are of no mean importance in the regulation of life. ${ }^{79}$ As was language. Diplomats mastered the usage of the ancien régime, 'these linguistic weapons of a bygone worldliness.' 80

The language and ceremonial reinforced certain expectations of behaviour. Diplomatic practice and ritual set the terms of engagement and conditioned, when it did not determine, the procedure at Utrecht. Both the public face of the congress and the private negotiations were grounded in the assumptions of a shared diplomatic code. Within the public framework of the congress, the ceremony and ritual flaunting of the trappings of power as seen, for example, in the gazettes, fireworks, songs, prints, poetry, and coins, underscored both the majesty of the various states and the emergence of a cosmopolitan Europe. Shared conventions on language, dress, etiquette, and ritual reaffirmed the international nature of that society. The informal contacts and the sociability expedited the give and take so integral to the old diplomacy and facilitated agreements in the ancien régime. It was, in the words of Scott, a 'concessive world... conducted by ambassadors who were members of the same international society.' ${ }^{81}$ Europeans' assumption of a common diplomatic culture helped make possible an international order. In the eighteenth century Burke and others thought of Europe as 'a commonwealth ... virtually one great state.'

76 Norbert Elias, The Court Society, translated by Edmund Jephcott (New York: Pantheon, 1983), 86-87.

77 Edmund Burke, The Writings and Speeches of Edmund Burke, vol. 9, ed. William B. Todd (Oxford: Clarendon Press, 1991), 114, 'Fourth Letter on a Regicide Peace.'

78 Edmund Burke, 'Letters on a Regicide Peace,' in The Works (London: Bell, 1893), 5: 208.

79 Edmund Burke, 'A Letter to a Member of the National Assembly in Answer to Some Objection to his book on French Affairs,' in Works of the Right Honourable Edmund Burke (London: Bohn, 1855), 2: 537.

80 Sarah Maza, Private Lives and Public Affairs: The Causes Célèbres of Prerevolutionary France (Berkeley: University of California Press, 1993), 307. 


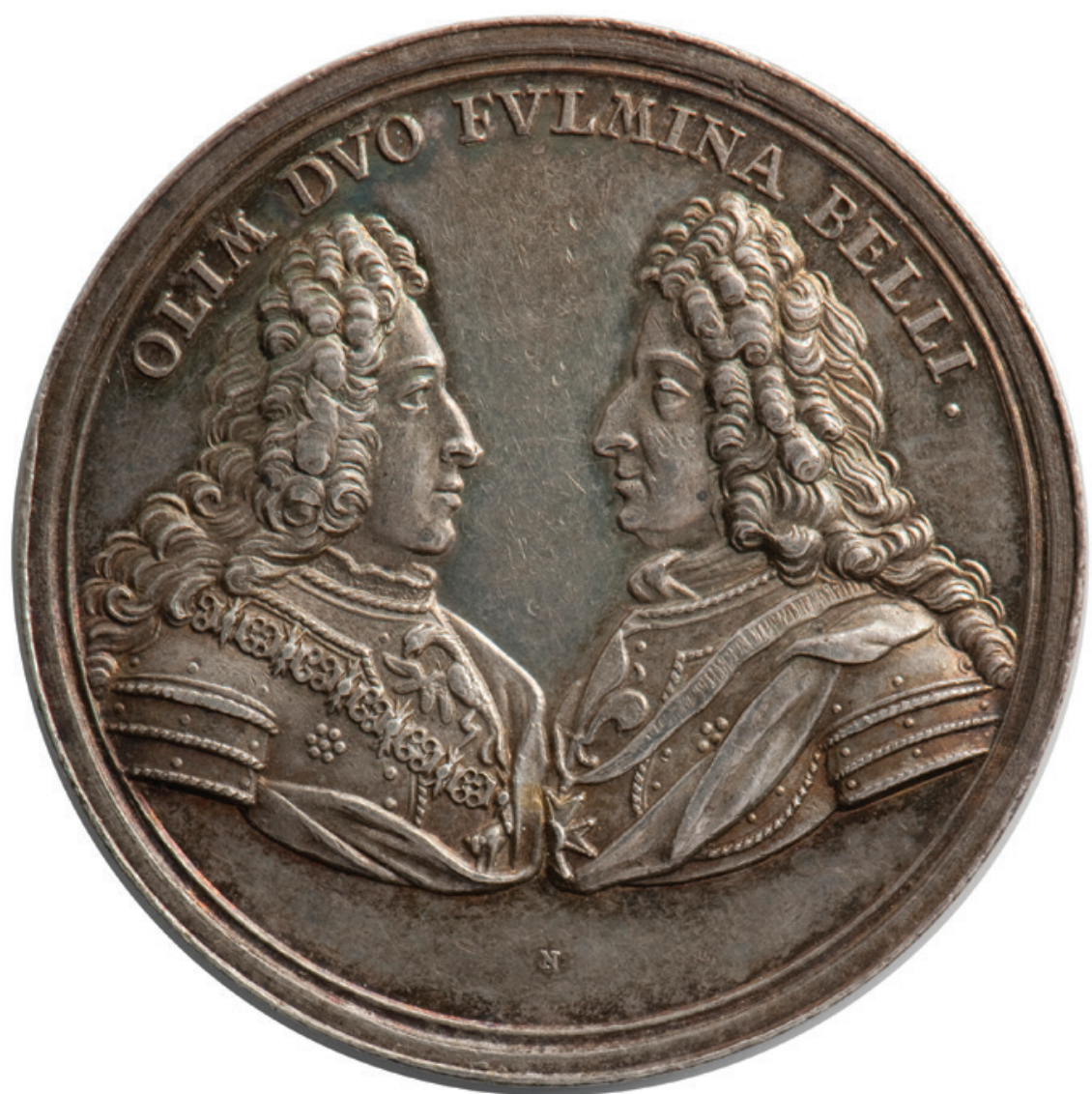

FIGURE 1.1 Medal in silver to Commemorate the Treaty of Rastatt, 1714. Design by Martin Brunner (1659-1725).

LANDESMUSEUM WÜRTTEMBERG, STUTTGART

For him 'correspondence in laws, customs, manners, and habits of life' had more force than treaties. 'They are obligations written in the heart.... 82 The Treaty of Rastatt provides the most telling example. The negotiations between the duc de Villars, one of the most outstanding generals of Louis XIV, and Prince Eugene of Savoy, arguably the foremost commander in Europe who served the Habsburgs, were expedited by their mutual respect and their friendship. Earlier in their careers they had fought together in the Ottoman campaigns.

82 Edmund Burke quoted in Gerald W. Chapman, Edmund Burke. The Practical Imagination (Cambridge, Mass: Harvard University Press, 1967), 185-186. 
At Rastatt, they dined and played cards. The medal issued by the French to commemorate that peace showed two thunderbolts of battle giving Europe peace: Olim duo fulmina belli, nunc instrumenta quietis (once two thunderbolts of war, now instruments of peace. $)^{83}$ Two who had successfully mounted the horses of war extended the olive branch of peace.

83 Linda Frey and Marsha Frey, 'Treaty of Rastatt,' in The Treaties of the War of the Spanish Succession, ed. Frey and Frey, 373-375. 